\title{
MECHANISED HARVEST OF ENERGY WOOD: STATE-OF-THE-ART AND NEW DEVELOPMENTS
}

\author{
Ralf Pecenka ${ }^{1}$, Jadir Nogueira da Silva ${ }^{2}$, Detlef Ehlert ${ }^{3}$ Gerd Volkhard Scholz
}

\begin{abstract}
Energy wood from fast growing trees, also called short rotation coppice (SRC) such as poplar, willow and eucalyptus, may provide a secure source of income for farmers, provided that production technologies, logistic chains and end user facilities are well designed in farmers' regional structures. One of the key problems at present is the lack of inexpensive harvesting machinery. Analyzing the process chain of fast growing trees, chip lines seem to be most costefficient for harvest, and the modification of forage harvesters is a promising option. But the high machine weight of forage harvesters is a serious disadvantage for harvest in rain-laden or mountainous regions. Furthermore, for economic operation of these expensive harvest systems cultivation areas of more than 300 ha are required. Therefore, a simple and low weight tractor-mounted mower-chipper for medium sized standard tractors has been developed. The chipper is designed for flexible harvest of wood from fast growing trees (max. stem diameter $15 \mathrm{~cm}$ ). The total weight of the harvester (tractor and chipper) is less than $50 \%$ of the forage harvester combination resulting in much more flexible field operation and lower harvest costs. The machine has been successfully tested in the last three harvest seasons on an area of more than $110 \mathrm{ha}$. At harvest of 4 years old poplars $(10-15 \mathrm{~cm}$ stem diameter $)$ an average field performance of 0.5 ha $\mathrm{h}^{-1}$ has been realized. Due to the robust design and performance of the prototype the development of a reinforced model is considered at present. Such a new model could be designed for harvest of poplar or eucalyptus trees with stem diameters of more than $20 \mathrm{~cm}$.
\end{abstract}

Keywords: Short rotation coppice, harvesting, wood chip, poplar, willow, eucalyptus

\section{RESUMO}

\section{COLHEITA MECANIZADA DE FLORESTAS ENERGÉTICAS: ESTADO DA ARTE E NOVAS SOLUÇÕES TÉNICAS}

A energia de biomassa florestal, em particular a de árvores de crescimento rápido, tais como choupo, salgueiro e eucalipto, pode constituir fonte segura de renda para os agricultores, desde que as tecnologias de produção, as cadeias logísticas e as instalações dos usuários finais sejam bem estruturadas regionalmente. Um dos principais problemas no momento é a falta de máquinas de colheita de custos reduzidos. Analisando-se a cadeia do processo produtivo de árvores de crescimento rápido, as linhas de chips parecem ser, em termos de custo, as mais indicadas para a colheita eficiente, todavia a modificação de colhedoras de forragem surge como uma opção promissora. O elevado peso das máquinas de colhedoras de forragem é, entretanto, séria desvantagem para uso em regiões montanhosas ou na estação chuvosa. Por outro lado, para que seja economicamente viável, o uso de maquinário pesado só é compensador quando utilizado em áreas de mais de 300 ha. Neste contexto, um trator cortador -picador de baixo peso foi desenvolvido com vistas a ser usado por empresas de médio porte. O picador é projetado para a colheita de madeira oriunda de árvores de crescimento rápido (máx. diâmetro do caule $15 \mathrm{~cm}$ ). O peso total do dispositivo de colheita desenvolvido (trator e picador) é 50\% inferior ao de uma encilhadora, o que, em operação de campo, possibilitou significativa redução nos custos de colheita. A máquina foi testada com sucesso nas últimas três épocas de colheita em uma área de mais de 110 ha. Na colheita de choupos de 4 anos de idade (diâmetro da haste 10-15 centímetros) obteve-se um desempenho médio de campo de $0,5 \mathrm{ha} \mathrm{h}^{-1}$. Devido ao design robusto e ao bom desempenho do protótipo, o desenvolvimento de um modelo reforçado está sendo considerado para um futuro próximo. Este novo modelo deverá ser projetado para a colheita de madeira de álamo ou eucalipto, com diâmetros de haste de mais de $20 \mathrm{~cm}$, com vistas ao aproveitamento com fins eneréticos.

Palavras-chave: colheita de madeira, aparas de madeira, choupo, salgueiro, eucalipto.

\section{Recebido para publicação em 18/11/2015. Aprovado em 15/02/2016.}

1 - Doutor-Eng. Mecânico, Pesquisador, ATB Potsdam-Bornim/Alemanha, rpecenka@atb-potsdam.de

2 - PhD, Professor Titular, Departamento de Engenharia Agrícola, UFV Viçosa-MG, jadir@ufv.br

3 - Doutor-Eng. Agrícola, Pesquisador, ATB Potsdam-Bornim/Alemanha, dehlert@atb-potsdam.de

4 - Doutor-Eng. Agrícola, Professor, Beuth-Hochschule Berlin/Alemanha, vscholz@beuth-hochschule.de 


\section{INTRODUCTION}

Energy wood is a promising option for sustainable production of biofuels in agriculture and it may help to secure the income of farmers. Therefore, cultivation of fast growing trees (short rotation coppice - SRC), such as poplar (Populus sp.), willow (Salix viminalis), and eucalyptus (Eucalyptus) is worldwide of increasing interest. In many European countries poplar and willow plantations are introduced in common agricultural practice. The cultivation area in Germany has been increased during the last five years from 2,000 ha to approx. 5,000 ha in year 2013 (SCHÜTTE, 2010; FNR, 2014). Over a period of 20 to 30 years, poplar yields of more than $10 \mathrm{t} \mathrm{DM} \mathrm{ha-1}$ $\mathrm{yr}^{-1}$ are possible even without any fertilization in Germany (SCHOLZ, KERN, KAULFUSS, 2010; SCHOLZ et al. 2011). In Brazil, where nearly the half of eucalyptus wood is energetically used, the cultivation area of eucalyptus is currently about 5 million ha and the yields of the usually fertilized plantations exceed partially $20 \mathrm{t} \mathrm{DM} \mathrm{ha}^{-1} \mathrm{yr}^{-1}$ (ABRAF 2012; IBÁ 2014; SANTOS et al., 2012).

Analyzing the current situation in the management of energy wood production in Europe, several problems in cultivation and mechanization can be observed. Depending on yield and cropping technology, harvesting costs are estimated to be 35 to $60 \%$ of the total costs of wood production from fast growing trees in Europe (HEISS, 2005;
BACH, 2007; SCHOLZ, 2007; SPINELLI et al.,, 2009; SCHWEIER; BECKER, 2012a and 2012b). Consequently, the optimization of harvest technologies is a prerequisite for cost-efficient production of energy wood.

\section{MATERIALS AND METHODS}

\section{Current status of harvest technology}

There are two harvest lines currently used at practice: Shoot Lines - where whole trees are harvested, stored and chipped later (cutand-storage line), and Chip Lines - where the trees are chipped immediately by the harvest machine (cut-and-chip line) - see Figure 1. Numerous publications can be found about all these harvesting technologies and their influence on logistic chains and storage processes in the last decades (SCHWEIER; BECKER, 2012a and 2012b; BERHONGARAY et al., 2013; STOKES; HARTSOUGH, 1994; HARTSOUGH; YOMOGIDA, 1996; HARTSOUGH; STOKES, 1997; PECENKA et al., 2014; SAVOIE et al., 2012). Advantages and disadvantages, costs and harvest capacities were presented and discussed. Analyzing the process chain, it can be concluded that the high investment costs for suitable harvest equipment, low flexibility regarding tree variety and cultivation scenario as well as high machine weight accompanied by problems during harvest in winter and low capacities are some of the most important obstructions at present.
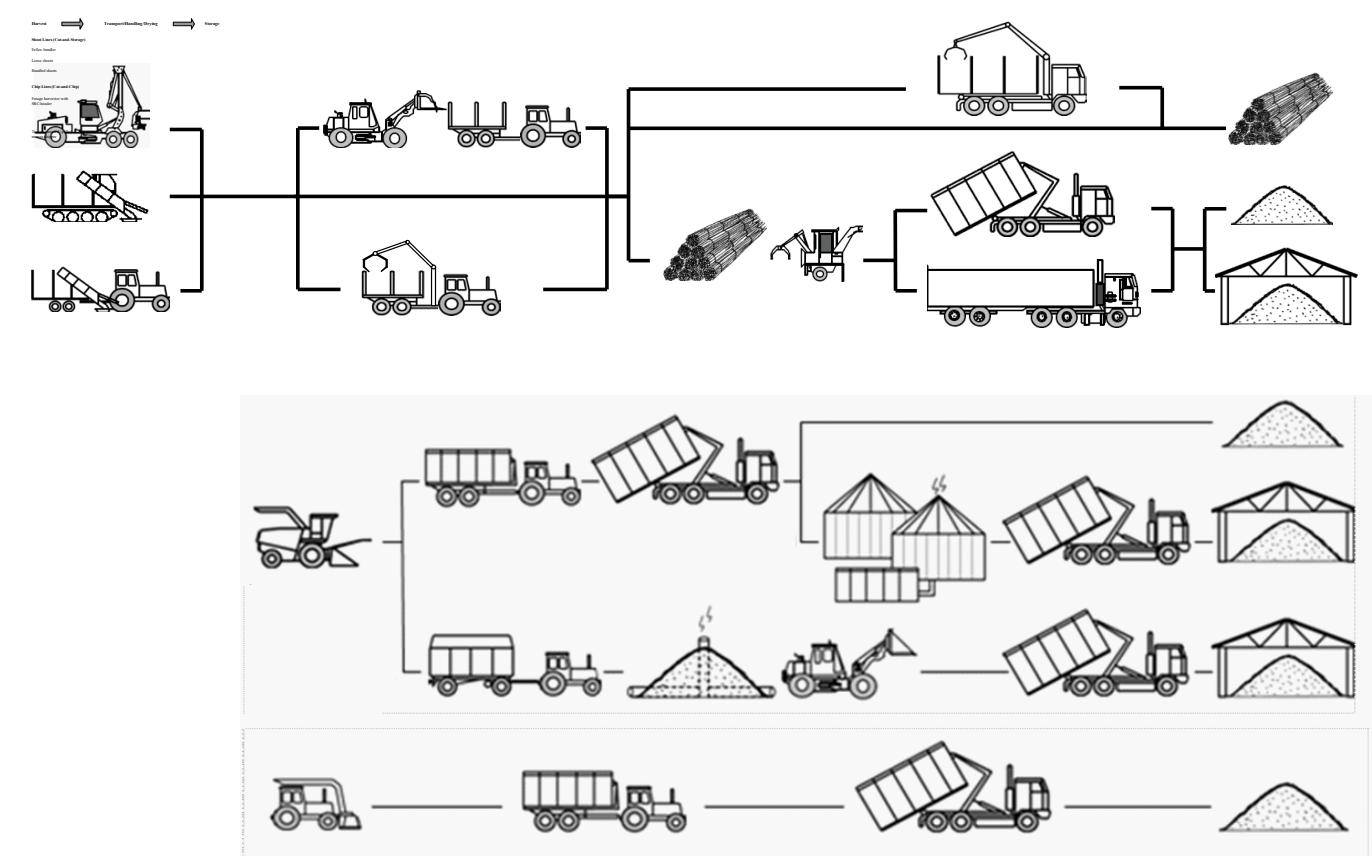

Figure 1. Harvest, storage, transport and drying technologies for fast growing trees 
With respect to minimum process steps and low production costs, chip lines with cutter-chippers are advantageous because mowing, chipping and conveying of chips on a transport unit can be performed by only one machine while driving. If the requirements regarding length distribution of the chips are fulfilled, the harvested material can be used without any further comminution in local heating plants.

In Europe, most chippers for poplar and willow harvest are based on forage harvesters because the installed cutter drum can be used for chipping and the discharge chute can fill transport vehicles. These harvesters are not used for forage production during winter, therefore the harvest of energy wood is an interesting option for increasing machine utilization. In response to this situation, specialized mower-feeder units have been developed. For almost all forage harvester models, additional mower-feeder units have been made commercially available in the last decade (Table 1).

As shown in Table 1, the mass of basic forage harvester vehicles range from 11 to $14 \mathrm{t}$. Together with the header units, a forage harvester equipped for energy wood averages approximately $15 \mathrm{t}$ in total mass and costs approximately 420,000 €. In addition, for the economic operation of these highly productive harvest systems, cultivation areas of more than 300 ha are required (SCHOLZ et al., 2009), if the harvester is used for wood alone. The required minimum acreage will be reduced, if the harvester is used for forage during summer. But the reduction will be small taking into account that a high-power forager is necessary to realize satisfying working speeds at harvest of energy wood, forest tires are indispensable to avoid damages, an enforced chipping drum is recommended and the cost of the wood header alone is approximately $100000 €$.

Another group of mower-chippers is based on the use of common agricultural tractors (Table 2). These machines are mounted in front or at the back of the tractor. The required tractor power is up to $400 \mathrm{~kW}$ (KWF, 2013). Most of these chippers also use a push bar to bend the trees and bring them in a horizontal position before chipping. Only a few developments have focused on harvest and chipping with mower-chippers of fast growing trees in an upright position (STUART et al., 1983; WIENEKE, 1993; DÖHRER, 1995). In contrast to forage harvester-based solutions, the cutting unit (drum, cone or disc) is integrated in the tractormounted machine. To provide the required power and efficiency, the chipping units are mostly PTO driven (power take-off). To drive the mowing and feeding units (screws, rollers or rotors), numerous hydraulic components, such as pumps, motors, valves, lines and oil tanks, are necessary. All these mechanical and hydraulic parts add up to machine masses from about 1 to 4 t. Together with the suitable basic tractor the complete harvesting unit can vary in mass and price over a wide range (Table 2). It should be noted that the maximum trunk diameter is very different for the various models. According to the working principle, e.g. the JF harvesters from NY VRAA are limited to 6 $\mathrm{cm}$. Therefore, only willows with an age of 2 or 3 years can be harvested.

Table 1. Forage harvester-based chippers for fast growing trees.

\begin{tabular}{|c|c|c|c|c|c|}
\hline $\begin{array}{l}\text { Basic vehicles/ } \\
\text { recommended } \\
\text { power }(\mathrm{KW})\end{array}$ & Mower-feeder & $\begin{array}{l}\text { Mass (kg) } \\
\text { Harvester/ } \\
\text { mower }\end{array}$ & $\begin{array}{l}\text { Price }(€) \\
\text { Harvester/ } \\
\text { mower }\end{array}$ & $\begin{array}{l}\text { Cutting } \\
\text { width } \\
(\mathrm{mm})\end{array}$ & $\begin{array}{c}\text { Max. stem } \\
\text { diameter } \\
(\mathrm{mm})\end{array}$ \\
\hline $\begin{array}{l}\text { Class Jaguar } \\
900-830 / 255\end{array}$ & Salix HS2 & $11,000 / 1,200$ & $337,000 / 98,000$ & 1000 & 80 \\
\hline $\begin{array}{l}\text { Krone Big X } \\
\text { / } 380\end{array}$ & Woodcut & $14,000 / 2,800$ & $353,000 / 89,500$ & 1500 & $<150$ \\
\hline $\begin{array}{l}\text { New Holland } \\
\text { FR 9000/ } 450\end{array}$ & $130 \mathrm{FB}$ & $12,900 / 2,100$ & $327,000 / 124,000$ & $\begin{array}{l}\text { Double row with } \\
750 \mathrm{~mm} \text { distance }\end{array}$ & 150 \\
\hline $\begin{array}{l}\text { John Deere } \\
7050 / 350 \\
\end{array}$ & CRL & $14,000 / 1,500$ & $260,000 / 95,000$ & $\begin{array}{l}\text { Double row with } \\
750 \mathrm{~mm} \text { distance }\end{array}$ & 100 \\
\hline Mean value & & Mass: 14,870 & Price: 420,880 & & \\
\hline
\end{tabular}


Table 2. Tractor-mounted mower-chippers for harvest of fast growing trees.

\begin{tabular}{lrclc}
\hline Machine & Mass $(\mathrm{kg})$ & Price $(€)$ & Field layout & Max. stem diameter $(\mathrm{mm})$ \\
\hline JENZ GMHT 140 & 3,500 & 85,000 & Single or double row & 140 \\
NYVRAA JF 192 & 900 & 21,000 & Single row & $50-60$ \\
NYVRAA JF Z20 & 1,500 & 28,000 & Double row & $30-40$ \\
SPAPPERI model RT & 1,800 & unknown & Double row & 180 \\
\hline Required standard tractors & $6,000-10,000$ & $75,000-200,000$ & & \\
$75-400 \mathrm{~kW}$ & & & & \\
\hline
\end{tabular}

A few other prototypes of mower-chippers have been developed using the chassis from self-propelled vehicles or tractors without a standardized three-point linkage. In 1986, a Gandini forage harvester prototype was designed for black locust and poplar plantations, but due to several technical problems the project was terminated in 1994 (BALDINI, FULVIO, 2009). In 1994, Salix Maskiner presented a concept of a special mowerchipper for willow named the Bender (BALDINI; FULVIO, 2009), and an enhanced version, the Bender 5, has been offered. The Austoft 7700/240 is an Australian harvester for sugar cane adapted for willow harvest (BALDINI; FULVIO, 2009; KOFMAN, 2012). The BR 600 biomass harvester, based on a self-propelled crawler tractor, has been presented by Plaisance Equipment (PLAISANCE, 2013).

Based on the analyses of the current status of harvesting equipment for fast growing trees, the following can be concluded:

- High harvest costs are one of the most limiting factors for increasing energy wood acreage in Europe;

- There is no universal low-cost harvester for fast growing trees available at practice scale. Such harvester should be flexible regarding variety (poplar, willow, and black locust), tree size (stem diameter $2-15 \mathrm{~cm}$ ), and field conditions (e.g., small fields, difficult soil conditions);

- A new principle for low-cost mower-chippers should be developed to support and increase the production of energy wood from fast growing trees.

\section{Development of a tractor-mounted mower- chipper}

\section{Basic requirements}

Due to the unsatisfactory situation in energy wood harvesting technology, a research project was initiated at the Leibniz Institute for Agricultural Engineering, Potsdam-Bornim, Germany (ATB) to develop a simple and low weight universal mowerchipper for stem diameters at base up to $15 \mathrm{~cm}$. The mass of the unit should be less than $1500 \mathrm{~kg}$, and it should be mounted in front of medium-sized standard tractors $(150-250 \mathrm{~kW})$. To avoid problems with uprooting or breaking of trees while mowing and chipping, the stem should remain in the upright position. Based on own harvest experiences and especially serious problems during harvest of older double row plantations of poplar in Germany it has been decided to develop a unit for harvest of single row plantations only (EHLERT, PECENKA, 2013). For economic and trouble-free harvesting from a long-term perspective, only single-row plantations should be established in the future.

For the systematic development of a new working principle for a tractor-mounted mowerchipper, the following four main features must be realized:

- Simple and robust design of the mower-chipper unit;

- Simple and safe feeding of the mower-chipper with trees of different sizes;

- Avoid felling the trees in a horizontal position before chipping;

- Simple and sure conveying of the chips to the transport units. 
Development of a simple and robust mowerchipper unit

The basic idea for the new mower chipper unit is shown in Figure 2. To minimize the number of powered parts, the functions of mowing, chipping and conveying of chipped material were realized by a compact and simple unit (tool rotor) rotating in a robust housing. For tree mowing, the tool rotor of the prototype is designed as a disc saw with an outer diameter of $1300 \mathrm{~mm}$. For chipping of the severed stems, knives set on spacer blocks are installed on the upper side of the disk saw. Contrary to most mowing disks in other harvesters, the tool rotor is solid rather than slotted, thus avoiding chips falling on the ground of the field. As a result of this arrangement, the theoretical maximum chip length is limited by the sum of the height of the spacer block and the chipping knife. For an optimal chipping process, a counter bar is installed on the housing. After chipping, the comminuted material is accelerated and moved to the outer edge of the housing at a rotation speed of $1000 \mathrm{rpm}$ towards the discharge opening.

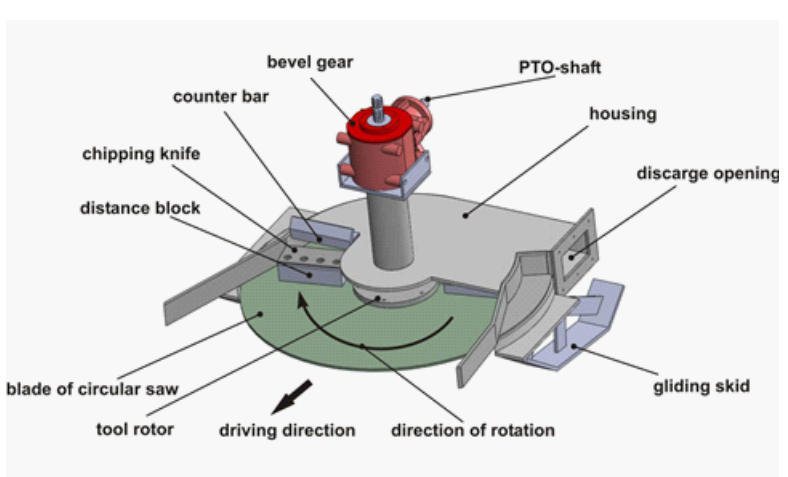

Figure 2. Principle of the developed mowerchipper unit.

Development of the periphery for safe feeding of trees in upright position and conveying of chips to transport vehicles

The development of a means for failure-free feeding of the mower-chipper unit proved to be the most complicated task. Finally, safe feeding of trees with diameters of up to $150 \mathrm{~mm}$ (single trees max. $180 \mathrm{~mm}$ ) can be realized by a combination of a fixed feeding auger and a spring loaded counter roller (Figure 3).

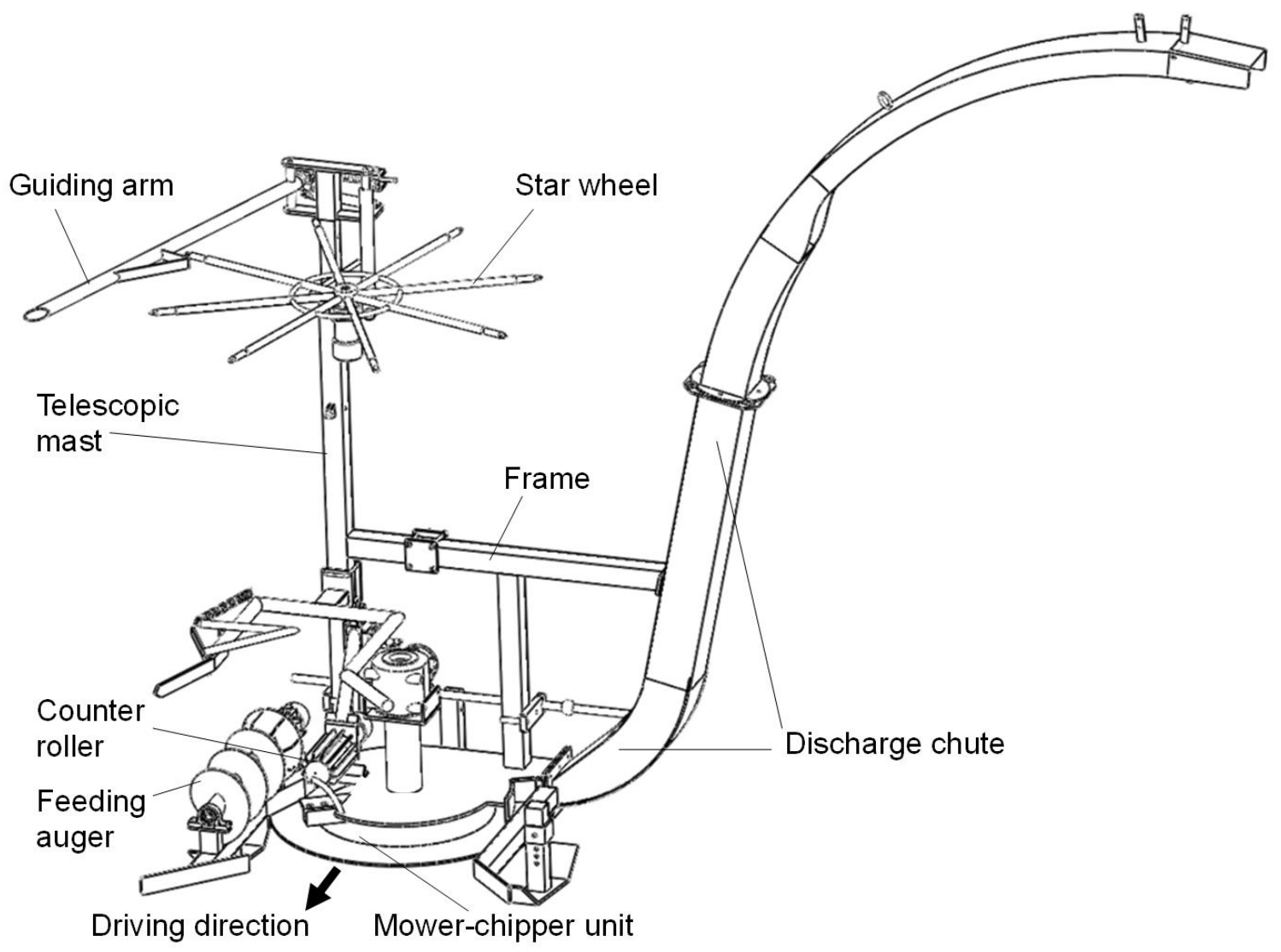

Figure 3. Principle of the developed mower-chipper. 
The field tests showed that trees after mowing sometimes fell ahead and sideways into horizontal positions, resulting in significant yield losses and poor chip quality (over length). To reduce these problems, the trees must be fixed before mowing. Fast growing trees can grow up to $10 \mathrm{~m}$ and more; therefore, they must be supported above their center of gravity, which can be realized by using a telescoped mast with additional guiding elements. The best guiding and conveying effect was achieved during the tests with the combination of an active hydraulically driven star-wheel and a guiding arm with a barb.

As shown in Figure 2, the chips of the cutterchipper unit are thrown off horizontally via the discharge opening. As a result, the material has to be deflected two times for nearby $180^{\circ}$ for filling transport units. Due to the high acceleration of the wood particles during the chipping process (as a result of the high speed of the chipping knife and distance bar) no blockages in the discharge shoot (Figure 3) were observed during the tests.

\section{RESULTS AND DISCUSSION}

Until April 2015 more than 110 ha of poplar, willow and black locust have been harvested with the new mower-chipper in Germany. The tests have shown that the basic working principle of mowing and chipping trees in an upright position has significant advantages. The breaking and uprooting of trees during cutting can be completely avoided. The stumps showed a clear cut surface after mowing with the circular saw.

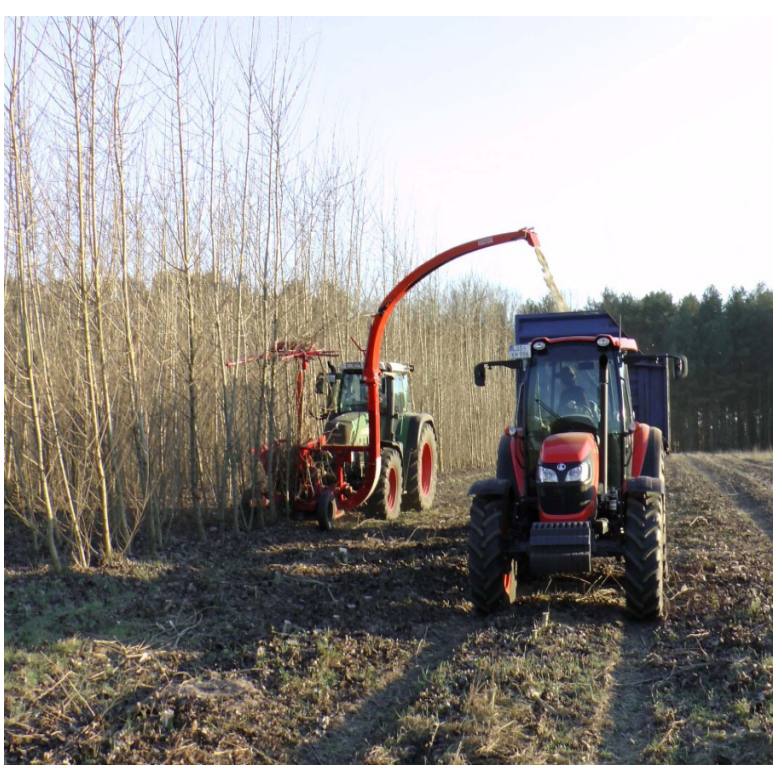

Figure 4. Prototype of the developed mowerchipper at harvest of poplar (2014).
The weight of the complete tractor-mounted mower-chipper was about $1400 \mathrm{~kg}$ (Figure 4). Tests performed in poplar plantations demonstrated the high potential of the new concept as a low cost mower-chipper for practical use on farms. The tool rotor was equipped with only one pair of knives for chipping during the tests. According to the height of the spacer blocks and chipping knives, the theoretical maximum length of the chips was 120 $\mathrm{mm}$. Trees with base diameters of up to $15 \mathrm{~cm}$ and a height of $12 \mathrm{~m}$ were harvested during the tests.

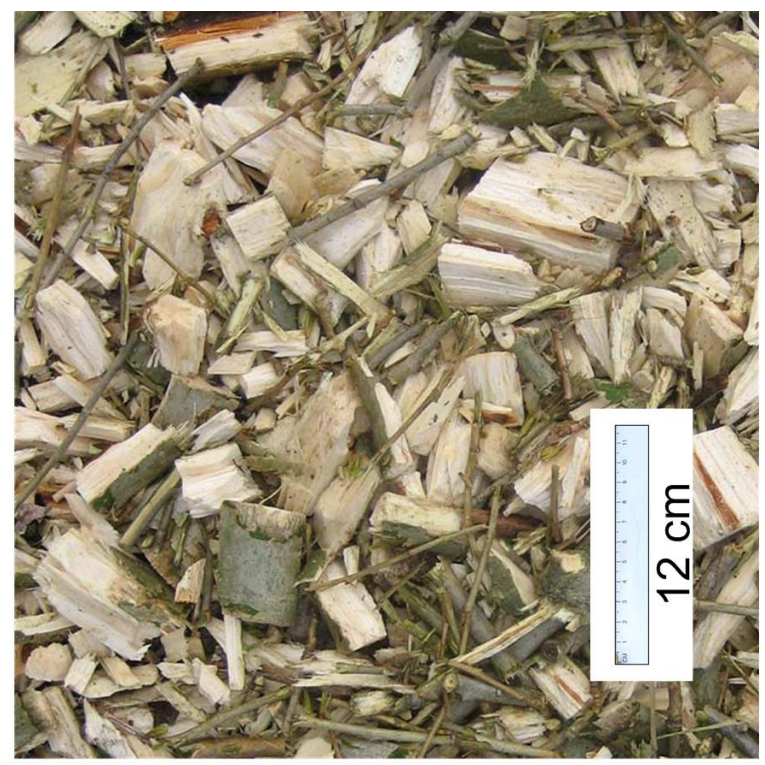

Figure 5. Example of wood chips from poplar harvested with the prototype.

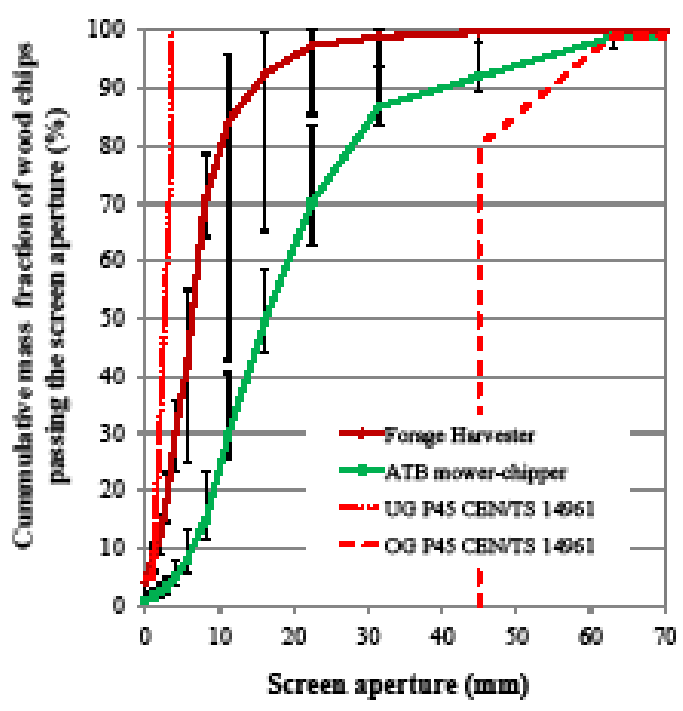

Figure 6. Particle size distributions of wood chips from poplar produced with different harvesters in 2013 (Forage harvester New Holland FR 9060 and prototype (ATB) of the tractor-mounted mower-chipper) 
As shown in Figure 5, the chips had a good quality for later drying during storage and firing in large-scale heating plants. Figure 6 shows a comparison of coarse chips produced with the novel mower-chipper at a cutting length of 75 $\mathrm{mm}$ and typical fine chips produced with a forage harvester (cutting length $25 \mathrm{~mm}$ ). If shorter chips similar to fine chips from forage harvesters have to be produced by the mower-chipper, the height of the spacer blocks can be reduced as well as the number of knifes can be increased.

Table 3. Technical data of the prototype of the developed mower-chipper.

\begin{tabular}{|c|c|}
\hline Machine parameter & Details \\
\hline Embodiment & Tractor-mounted at front \\
\hline Total mass & approx. $1000 \mathrm{~kg}$ \\
\hline Mower disk diameter & $1300 \mathrm{~mm}$ \\
\hline Tool rotor speed & $1000 \mathrm{rev} \mathrm{min}^{-1}$ \\
\hline Total power requirement & $150-200 \mathrm{~kW}$ \\
\hline Max. hydraulic pressure & 180 bar \\
\hline Hydraulic flow rate & $501 \mathrm{~min}^{-1}$ \\
\hline Max. stem diameter & $15 \mathrm{~cm}$ \\
\hline Chip length & adjustable: $20-120 \mathrm{~mm}$ \\
\hline $\begin{array}{l}\text { Driving speed during } \\
\text { chipping* }\end{array}$ & $3-5 \mathrm{~km} \mathrm{~h}^{-1}$ \\
\hline Operative capacity* & $12-18 \mathrm{t}_{\mathrm{dm}} \mathrm{h}^{-1}$ \\
\hline Field performance* & $0.5 \mathrm{ha} \mathrm{h}^{-1}$ \\
\hline Productivity* & $15 \mathrm{t}_{\mathrm{dm}} \mathrm{h}^{-1}$ \\
\hline
\end{tabular}

The estimated economic advantages of tractormounted mower-chippers in comparison to forage harvesters presented in earlier studies (EHLERT, PECENKA, 2013) were based on effective speeds at harvest of approx. $3 \mathrm{~km} \mathrm{~h}^{-1}$, versus effective harvest capacities of 0.4 to $0.8 \mathrm{ha} \mathrm{h}^{-1}$. As shown in Table 3, effective speeds of 3 to $5 \mathrm{~km} \mathrm{~h}^{-1}$ were realized with the test unit. The tests were very promising for the future exploitation of the economic advantages of tractor-mounted mowerchippers in practice. Moreover, to exploit the full capacity of the mower-chipper unit tractors with capacities of round about $200 \mathrm{~kW}$ should be used.

\section{CONCLUSIONS}

- A commercial model of the mower-chipper for fast growing trees has been designed, built and tested successfully and will be available for the next harvest season in the European winter 2015/2016;

- Due to the robust design and good performance of the tested prototype and with a few modifications a reinforced model will be, for sure, able for harvesting more than 6 years old poplars as well as eucalyptus trees with stem diameters of $20 \mathrm{~cm}$ and more.

\section{REFERENCES}

ABRAF 2012. Dados estatísticos de eucalypto. Associação Brasileira de Produtores de Florestas Plantadas, Brasilia.

BALDINI, S., FULVIO, D. 2009. Short Rotation Forestry: Mechanization for the conditions of Italy. Mondo Macchina 18. p.36-43.

BACH, H. 2007. Willow Production and marketing in Denmark. Bornimer Agrartechnische Berichte 61, p.152-157.

BERHONGARAY, G., EL KASMIOUI, O., CEULEMANS, R. 2013. Comparative analysis of harvesting machines on an operational high-density short rotation woody crops (SRWC) culture: Oneprocess versus two-process harvest operation. Biomass and Bioenergy 58. p.333-342.

DÖHRER, K. 1995. Harvest technique for wood fields. Die Holzzucht 49. p.15-17.

EHLERT, D., PECENKA, R. 2013. Harvesters for short rotation coppice: Current status and new solutions. International Journal of Forest Engineering 24. p.170-182.

FNR 2014. Fachagentur für Nachwachsende Rohstoffe - Cultivation area of renewable resources 2013. http://mediathek.fnr.de/grafiken/ anbauflache-fur-nachwachsende-rohstoffe-2013grafik.html. 31.01.2014. 
HARTSOUGH, B.R., YOMOGIDA, D. 1996. Compilation of state-of-the-art mechanisation technologies for short-rotation woody crop production. Research Report, University of California, Biological and Agriculture Engineering Department, Davis (US).

HARTSOUGH, B.R., STOKES, B.J. 1997. Short rotation forestry harvesting - systems and costs. In Proceedings of the 1997 International Energy Agency: Bioenergy task 7, activity 2.1 and activity 4.3 workshop, Melrose, (GB).

HEISS, M. 2005. Auf Achievable gross margins from SRC in Austria. In Proceedings of the Fachtagung Energieholzbereitstellung, Wieselburg, AT.

IBÁ 2014. Indústria Brasiliera de Árvores. Pöyry Consultoria em Gestão e Negócios Ltda., São Paulo.

KOFMAN, P. 2012. Harvesting Short Rotation Coppice Willow. COFORD Harvesting/Transport 29. p.1-6.

KWF 2013. Think first than invest, KWFmarket overview for harvest technique for SRC. Groß-Umstadt: Kuratorium für Waldarbeit und Forsttechnik e.V., http://www.kwf-online.org/ fileadmin/dokumente/Bioenergie/Dokumente/ Kup-Ernter_2011.pdf. 22.05.2013.

PECENKA, R., LENZ, H., IDLER, C., DARIES, W., EHLERT, D. 2014. Development of biophysical properties during storage of poplar chips from 15 ha test fields. Biomass Bioenergy 65. p.13-19.

PLAISANCE: mulchers, broyeur-récupérateur. Plaisance Equipments. http://www.plaisanceequipements.com. 22.05.2013

SANTOS, L.C., CARVALHO, A.M.L.; PEREIRA B.L.C., OLIVEIRA, A.C., DE CÁSSIA, A.O.C., TRUGILHOV, P.F. 2012. Propriedades da madeira e estimativas de massa, carbono e energia de clones de Eucalyptus plantados em diferentes locais. Rev.
Árvore vol.36 no.5 Viçosa. p.971-980

SAVOIE, P., CURRENT, D., ROBERT, F.S., HÉBERT, P.L. 2012. Harvest of natural shrubs with a biobaler in various environments in Québec, Ontario and Minnesota. Applied Engineering in Agriculture 28. p.795-801

SCHOLZ, V. 2007. Mechanization of SRC production. Bornimer Agrartechnische Berichte 61, p.130-143.

SCHOLZ, V., ECKEL, H., HARTMANN, S. 2009. Processes and costs of SRC cropping on agricultural land. In Die Landwirtschaft als Energieerzeuger. KTBL-Schrift 476. p.67-80.

SCHOLZ, V., EHLERT, D., HOFFMANN, T., KERN, J., PECENKA, R. 2011. Cultivation, harvest and storage of short rotation coppice Long-term field trials, environmental effects and optimization potentials. Journal of Agricultural Machinery Science 7. p.205-210

SCHOLZ. V., KERN, J., KAULFUSS, P. 2010. environmental effects of energy crop cultivation Results of a long-term trial. Agronomy Research 8 . p. $445-452$

SCHÜTTE, A. 2010. Research and development for cultivation and utilization of wood from agriculture. In Proceedings of the Symposium Agrarholz 2010, Fachagentur für Nachwachsende Rohstoffe, Berlin, (DE).

SCHWEIER, J., BECKER, G. 2012a. Harvesting of short rotation coppice-harvesting trials with a cut and storage system in Germany. Silva Fennica, 46. p.287-299.

SCHWEIER, J., BECKER, G. 2012b. New Holland forage harvester's productivity in short rotation coppice: Evaluation of field studies from a German perspective. International Journal of Forest Engineering 23. p.82-88.

SPINELLI, R., NATI, C., MAGAGNOTTI, N. 2009. Using modified foragers to harvest short- 
rotation poplar plantations. Biomass and Bioenergy 33. p.817-821.

STOKES, B., HARTSOUGH, B.R. 1994. Mechanization in short rotation intensive culture (SRIC) forestry. In Proceedings of 6th National Bioenergy Conference, Reno-Sparks, (US).
STUART, W.B., MARLEY, D.S., TEEL, J.B. 1983. A prototype short rotation harvester. Proceedings of the 7th International FPRS Industrial Wood Energy Forum '83, Nashville, (US).

WIENEKE, F. 1993. Mower-chipper for energy plantations of poplar and willow. Landtechnik 48. p.646-647. 